\title{
CAD wt Allele
}

National Cancer Institute

\section{Source}

National Cancer Institute. CAD wt Allele. NCI Thesaurus. Code C50949.

Human CAD wild-type allele is located within 2p22-p21 and is approximately $26 \mathrm{~kb}$ in length. This allele, which encodes CAD protein, plays a role in de novo pyrimidine nucleotide biosynthesis. 